Correction

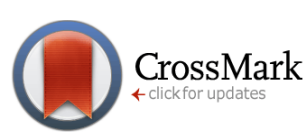

CORRECTION: Adipose derived stem cell transplantation is better than bone marrow mesenchymal stem cell transplantation in treating hindlimb ischemia in mice

\title{
Ngoc Bich Vu ${ }^{1}$, Lan Thi Phi ${ }^{1}$, Thuy Thi-Thanh Dao ${ }^{1}$, Ha Thi-Ngan Le ${ }^{1}$, Van Thanh $\mathrm{Ta}^{2}$, Phuc Van Pham ${ }^{1,3, *}$
}

\footnotetext{
${ }^{1}$ Laboratory of Stem Cell Research and Application, University of Sciences, Vietnam National University, Ho Chi Minh City, Viet Nam

${ }^{2}$ Hanoi Medical University, Ha Noi, Vietnam

${ }^{3}$ Falcuty of Biology and Biotechnology, University of Sciences, Vietnam National University, Ho Chi Minh City, Vietnam
}

*For correspondence:

pvphuc@hcmuns.edu.vn

Competing interests: The authors declare that no competing interests exist.

Received: 15 March 2017

Accepted: 20 April 2017

Published: 30 April 2017

Copyright The Author(s) 2017. This article is published with open access by BioMedPress (BMP).

This article is distributed under the terms of the Creative Commons Attribution License (CC-BY 4.0) which permits any use, distribution, and reproduction in any medium, provided the original author(s) and the source are credited.
The Figure 5 of the article "Adipose derived stem cell transplantation is better than bone marrow mesenchymal stem cell transplantation in treating hindlimb ischemia in mice" that published in 29 Sept 2016, at Vol 3, Issue 9, from page 844-856 (DOI: 10.7603/s40730-016-0046-0) as below

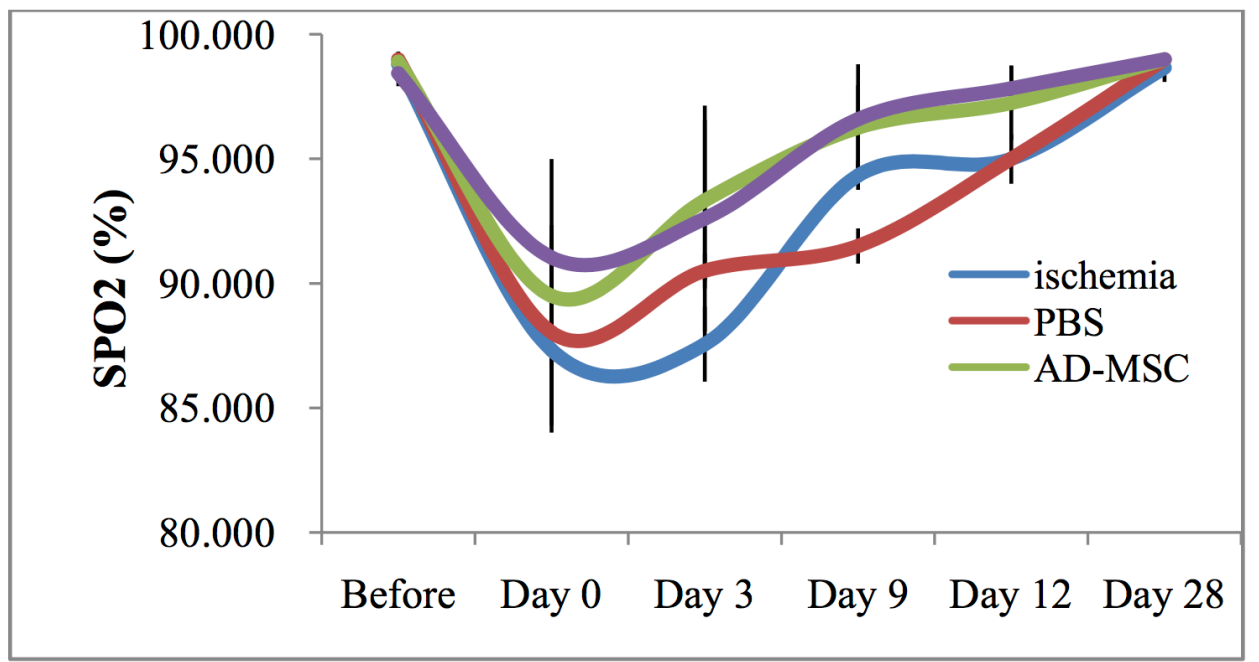




\section{Biomedical}

that lacked the legend for the violet line should be corrected as:

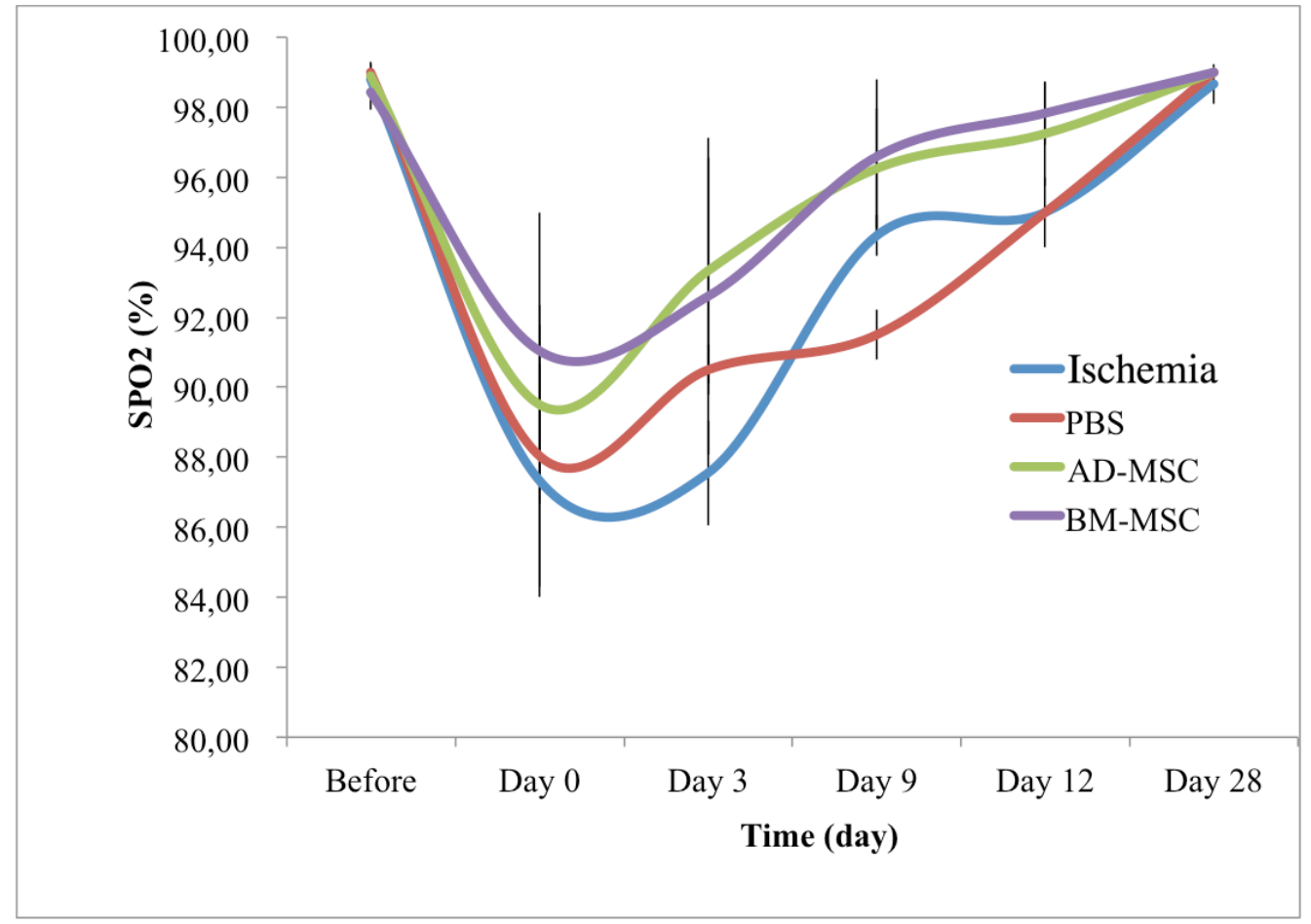

The violet line demonstrated "BM-MSC". 